\title{
Psykisk syge lovovertrædere i et komparativt lys
}

\author{
Af Simon Kamber ${ }^{1}$
}

\begin{abstract}
This paper was written in connection with an ongoing postgraduate project examining the rules regarding mentally ill offenders in Norway, Denmark and Sweden. The paper outlines the overall scope of the project and then presents preliminary results in two specific areas: A dogmatic analysis of the rules in the three countries and a functional comparative analysis.
\end{abstract}

Denne artikel er skrevet i forbindelse med præsentationen af et igangværende ph.d.-projekt om psykisk syge lovovertrædere i nordisk strafferet. Projektet er påbegyndt $\mathrm{i}$ september $2010 \mathrm{og}$ forventes afsluttet $\mathrm{i}$ august 2014.

Det er et almindeligt udbredt strafferetligt koncept at en lovbryder som ikke er ved sine fulde fem giver anledning til særlige strafferetlige udfordringer. Begrundelserne for at give psykisk syge særlig strafferetlig behandling har været mange, heriblandt manglende ansvarlighed, manglende påvirkelighed for straftruslen eller det synspunkt at det ganske enkelt er humanitært uforsvarligt at fængsle personer med visse psykiske lidelser.

Det varierer fra land til land hvilke regler som er indført for at imødegå denne udfordring. Selv imellem de nordiske lande, som ellers har en fælles strafferetlig tradition, ses markante forskelle på hvordan reglerne om psykisk syge lovovertrædere er udformet. Denne kombination af sammenlignelige retssystemer og forskellige tilgange til spørgsmålet om psykisk syge lovovertrædere danner et ideelt udgangspunkt for en retskomparativ undersøgelse.

Hensigten med denne artikel er for det første at give et overblik over projektet som helhed og tilgangen til den komparative undersøgelse, for det andet at præsentere nogle foreløbige resultater, og for det tredje at diskutere udvalgte forhold omkring psykisk syge i nordisk strafferet.

I artiklens første del vil jeg give et overblik over projektets overordnede linjer og introducere nogle af de centrale spørgsmål som har været eller vil blive genstand for undersøgelse. Derefter vil jeg præsentere reglerne om psykisk syge lov-

* Title in English: Mentally ill offenders from a comparative perspective. 
ovetrædere i de tre lande, Norge, Danmark og Sverige, som indgår i undersøgelsen. Endelig vil jeg kommentere på nogle bemærkelsesværdige forhold omkring de tre regelsæt og de psykiatriske institutioner som er tilknyttet anvendelsen af reglerne.

\section{Ph.d.-projektet »Psykisk syge lovovertræedere i nordisk strafferet«}

Målet med projektet er at bidrage til forståelsen af psykisk syge lovovertræderes stilling i nordisk ret, og retsreglernes betydning i denne forbindelse. Metoden for projektet er funktionel komparativ ret, forstået på den måde at der tages udgangspunkt i de funktioner de strafferetlige regler og (rets)psykiatriske institutioner tjener både i forhold til samfundets behov og den psykisk syges behov. Projektet omfatter retssystemerne i Norge, Danmark og Sverige. De tre lande er valgt dels for at tage udgangspunkt i en fælles retsudvikling, dels for at undgå nogle af de sprogbarrierer som ville udgøre en udfordring for en bredere nordisk undersøgelse.

Som fundament for undersøgelsen gøres nogle retsteoretiske overvejelser over strafferettens forskellige formål, og hvordan de kan indarbejdes i en funktionel analyse. Det primære fokuspunkt i denne del af projektet er straffesystemets begrundelser: Hvilke forskellige baggrunde for straffesystemet omtales i den strafferetlige og kriminologiske litteratur, og hvordan spiller de ind på det konkrete lovgivningsarbejde og retsanvendelsen?

Disse metodologiske og retsteoretiske overvejelser danner grundlag for afgrænsningen af projektet og for den komparative analyse. Som grundlag for afgrænsning kan en afklaring af reglernes funktion bidrage til at undgå en afgrænsning der i realiteten tager udgangspunkt $i$ et enkelt retssystems dogmatiske forhold. Som analytisk værktøj kan en funktionel tilgang bidrage til at afdække interaktionen mellem retspsykiatrien og det strafferetlige system, og mellem de forskellige formål som strafferetten søger at tjene.

Parallelt med de retsteoretiske overvejelser foretages en undersøgelse af retssystemet i de tre lande. Denne undersøgelse bygger i højere grad på traditionel dogmatisk metode, hvor de strafferetlige regler om psykisk syge lovovertrædere fremlægges og kategoriseres. Det er denne undersøgelse der vil danne udgangspunkt for størstedelen af de følgende afsnit.

På baggrund af de retsteoretiske overvejelser og den dogmatiske undersøgelse foretages en retskomparativ analyse af reglerne i de tre lande. Det undersøges hvilke principielle og reelle forskelle der er på de tre landes retssystemer på dette område, og hvad baggrunden er for disse forskelle. I analysen fokuseres særligt på hvordan, og i hvilket omfang, principielle overvejelser om straffens begrun- 
delser spiller ind i lovgivningsarbejdet og det praktiske arbejde, og hvilken rolle lovteksten spiller i denne proces.

\section{Grundlæggende distinktioner}

Inden de enkelte retssystemer gennemgås, er det værd at gøre et par bemærkninger om to grundlæggende distinktioner jeg vil gøre ved kategoriseringen af de strafferetlige regler om psykisk syge lovovertrædere.

Den første distinktion er mellem regler der begrænser adgangen til at anvende strafsanktioner, og regler der giver mulighed for at påtvinge behandling gennem det strafferetlige system. I alle tre lande findes regler der begrænser muligheden for at idømme strafferetlige sanktioner til personer der lider af visse former for psykiske lidelser. Disse vil blive omtalt som negative kriterier. Ved siden af disse regler er der i hvert af de tre lande regler der giver mulighed for at idømme en tiltalt psykiatrisk behandling. Kriterierne for en sådan reaktion vil blive omtalt som positive kriterier.

Den anden distinktion er mellem retspsykiatriske og strafferetlige kriterier. Både de positive og de negative kriterier bygger på kriterier der i et vist omfang kan spores til enten psykiatrisk eller strafferetlig terminologi. Retspsykiatriske kriterier henviser til sygdomskategorier eller lægefaglige vurderinger. Strafferetlige kriterier er formuleret $i$ termer hentet fra retlig tankegang, for eksempel ansvar, fare eller tilregnelighed. Det er ikke afgørende for kategoriseringen hvilken faggruppe som i sidste ende har kompetencen til at vurdere spørgsmålet i det konkrete tilfælde.

\section{Norsk ret}

Den norske regel som negativt afgrænser strafansvaret for alvorligt psykisk syge lovovertrædere, findes i straffelovens $\S 44$. Grundformen af denne bestemmelse har været stort set uændret siden 1929, mens den nuværende formulering af bestemmelsen stammer fra lovrevisionen i 1997 (ikr. 2002). Før revision var der ikke mulighed for at idømme psykiatrisk behandlingsdom som alternativ, men hvis farlighedskravet var opfyldt kunne der i stedet dømmes til sikring. Sikringsreaktionen gav mulighed for at tilbageholde farlige lovovertrædere, såvel psykisk syge som udviklingshæmmede og tilregnelige, med henvisning til samfundets sikkerhed. Ved revisionen i 1997 blev sikringsinstituttet erstattet med mere specialiserede reaktioner over for de tre grupper. For psykisk syges vedkommende indførtes reaktionen »dom på overføring til tvungent psykisk helsevern«.

Straffelovens $\S 44$, stk. 1 konstaterer at »Den som på handlingstiden var psykotisk eller bevisstløs straffes ikke«. Straffriheden knyttes således direkte til til- 
stedeværelsen af en af de pågældende tilstande. »Psykotisk « er et psykiatrisk begreb som dækker over en tilstand der medfører hallucinationer, vrangforestillinger eller bestemte former for abnorm adfærd. ${ }^{2}$ Bevisstløs anvendes ikke i sin mere almindelige sproglige betydning, men dækker over en tilstand som, trods den ikke er psykotisk, medfører at den pågældende ikke er bevidst om sine handlinger. $^{3}$

Den norske $\S 44$ udgør således et såkaldt »medicinsk « kriterium for straffrihed. Heri ligger at den manglende strafbarhed udelukkende bygger på retspsykiatriske kriterier.

Det positive kriterium for at dømme til psykiatrisk behandling findes i den norske straffelovs $\S 39$. Efter denne bestemmelse kan en lovovertræder som er straffri efter $\S 44$, overføres til tvungent psykisk helsevern. Der stilles to betingelser for en sådan reaktion: For det første skal der være tale om kriminalitet af en vis alvorlighed. Enten skal der være tale om »alvorlig voldsforbrytelse, seksualforbrytelse, frihetsberøvelse, ildspåsettelse eller annen alvorlig forbrytelse (...)«, eller også skal der være tale om et gentagelsestilfælde af mindre alvorlig kriminalitet af samme art. I begge tilfælde stilles samtidig krav om fare for gentagelse af alvorlig kriminalitet.

For det andet skal dom på overføring til tvungent psykisk helsevern anses for nødvendigt for at værne samfundet. Dette nødvendighedskrav strækkes forholdsvist vidt, og det er således blandt andet et krav at igangværende behandling ikke anses for tilstrækkelig til at forhindre yderligere kriminalitet. ${ }^{4}$

Indholdet i en dom på overføring til tvungent psykisk helsevern fastlægges i psykisk helsevernslovens kap. 5, og svarer i store træk til forløbet af administrativt besluttet tvungen behandling. Der stilles dog krav om en indledende tvangsindlæggelse på 3 uger, og påtalemyndigheden tildeles klageadgang ved visse beslutninger, for eksempel om udskrivning fra døgnophold.

Antallet af domme på overføring til tvungent psykisk helsevern er behæftet med en vis usikkerhed, da der før 2012 ikke har fundet central registrering af dommene sted. Det står dog klart at der er tale om en forholdsvist sjældent anvendt reaktion. Et udvalg nedsat til at evaluere de nye reaktioner rapporterer om mellem 7 og 15 nye domme årligt. ${ }^{5}$

\section{Dansk ret}

Den danske regel som negativt afgrænser strafansvaret for alvorligt psykisk syge lovovertrædere findes i straffelovens $\S 16$. Den positive regel som giver mulighed for idømmelse af foranstaltningsdomme findes i straffelovens $\S 68$. Begge be- 
stemmelser har været udsat for revisioner undervejs, men svarer i det store hele indholdsmæssigt til de oprindelige bestemmelser i straffeloven af $1930 .^{6}$

Kriteriet for straffrihed efter $\S 16$ er at lovovertræderen på gerningstidspunktet var »[utilregnelig] på grund af sindssygdom eller [en tilstand] der må ligestilles hermed «. Denne formulering indebærer to separate kriterier som skal være opfyldte for at straffriheden indtræder.

Det første kriterium er retspsykiatrisk: Den pågældende skal, på gerningstidspunktet, lide af en »sindssygdom eller tilstand, der må ligestilles hermed «. Kriteriet sindssygdom er ensbetydende med det psykiatriske begreb »psykose «, ${ }^{7}$ mens de »ligestillede tilstande « omfatter en række tilstande der, selv om de ikke i medicinsk forstand er psykoser, medfører en tilsvarende påvirkning af virkelighedsopfattelsen. »Sindssygdom « henviser til tilstedeværelsen af en sygdom af psykose-kategorien, men stiller ikke krav om at den pågældende sygdom på gerningstidspunktet skal give sig udslag i psykotiske symptomer. Modsat det norske krav om at lovovertræderen skal være "psykotisk «, vil det danske kriterium således kunne opfyldes selv om den pågældende ikke aktuelt udviser psykotiske symptomer. ${ }^{8}$

Det andet kriterium for straffrihed er strafferetligt: Den pågældende skal, på gerningstidspunktet, have været »utilregnelig « på grund af tilstanden. Ordet utilregnelig anvendes her i den ældre betydning af en person som ikke kan gøres ansvarlig for sine handlinger. Det juridiske indhold i kriteriet er ikke velafgrænset. Der er tale om en bred vurdering af om den pågældende tilstand er af en sådan karakter at det bør give sig udslag i straffrihed i det konkrete tilfælde. Som momenter der kan indgå i vurderingen, kan nævnes handlingens karakter, den pågældendes modtagelighed over for straftruslen og hvorvidt tilstanden må antages at have påvirket handlingen. ${ }^{9}$

Frifindes en tiltalt for straf efter $\S 16$, giver straffelovens $\S 68$ mulighed for at træffe bestemmelse om »andre foranstaltninger, der findes formålstjenlige for at forebygge yderligere lovovertrædelser«. De mulige foranstaltninger spænder fra tilsyn eller bestemmelser vedrørende opholdssted, til anbringelse i hospital for sindslidende.

Kriteriet for at idømme foranstaltning er således meget lavt. Udover at bestemmelsen er betinget af en frifindelse efter $\S 16$, stilles der blot krav om at foranstaltningen anses for »formålstjenlig for at forebygge yderligere lovovertrædelser«.

Den lave tærskel for foranstaltninger kombineret med den store fleksibilitet i valget af reaktion afspejles i antallet af reaktioner. En årlig opgørelse fra justitsministeriet viser at der i 2012 blev afsagt 573 foranstaltningsdomme over psykisk 
syge lovovertrædere. Langt størstedelen af disse (527) lød på behandling med mulighed for indlæggelse. ${ }^{10}$

\section{Svensk ret}

Modsat de norske og danske regler udgøres det negative kriterium i Sverige ikke af en begrænsning af strafansvaret. I brottsbalken fandtes indtil 2008 et forbud mod at idømme fængsel for en lovovertrædelse begået under påvirkning af en »allvarlig psykisk störning«. Bestemmelsen modsvaredes af $\S 31: 3$ som gav mulighed for at idømme »rättspsykiatrisk vård «.

I 2008 blev bestemmelsen i brottsbalkens $\S 30: 6$ ændret således at der nu er mulighed for at dømme til fængsel på trods af at den pågældende var påvirket af en »allvarlig psykisk störning«. En fængselsdom forudsætter dog at særlige grunde taler for det. Som særlige grunde nævnes i bestemmelsen: At lovovertrædelsen har høj strafværdighed, at den tiltalte ikke har, eller har begrænset, behov for psykiatrisk behandling, at den pågældende tilstand er selvpåført eller omstændighederne i øvrigt. Udgangspunktet er dog stadig at fængselsstraf ikke idømmes for lovovertrædelser begået under påvirkning af en »allvarlig psykisk störning«, og forbuddet mod straf er fortsat ufravigeligt hvis den pågældende på grund af lidelsen har »saknat förmåga att inse gärningens innebörd eller att anpassa sitt handlande efter en sådan insikt[..] «.

Begrebet »allvarlig psykisk störning« svarer ikke direkte til et psykiatrisk diagnosebegreb, men omfatter såvel psykotiske og psykoselignende tilstande som en række stærke tvangsmæssige tilstande. ${ }^{11}$

Den positive bestemmelse om dom til behandling findes i brottsbalkens $\S 31: 3$, som angiver betingelserne for at dømme til rättspsykiatrisk vård. Betingelserne for en sådan dom er først og fremmest at en tiltalt som på domstidspunktet lider af en »allvarlig psykisk störning «, samt at der er tale om en forbrydelse hvor sanktionen ikke kan begrænses til bøde. Derudover skal det med hensyn til den pågældendes tilstand og personlige forhold i øvrigt være påkrævet at han indlægges på en psykiatrisk institution.

En dom på rättspsykiatrisk vård indebærer som udgangspunkt indlæggelse, men patienten kan overføres til ambulant behandling hvis indlæggelse ikke længere er nødvendig, efter reglerne i lag om rättspsykiatrisk vård. Hvis lovovertrædelsen er begået under påvirkning af en »allvarlig psykisk störning «, og hvis denne medfører risiko for tilbagefald til alvorlig kriminalitet, kan retten træffe bestemmelse om at udskrivning forudsætter domstolsprøvelse. Findes der hverken grundlag for fængselsstraf eller rättspsykiatrisk vård, har domstolen efter $\S 30: 6$, stk. 3 mulighed for at undlade straf. 
Antallet af domme til rättspsykiatrisk vård ligger stabilt mellem 300 og 400 om året. I omtrendt to tredjedele af dommene stilles krav om domstolsprøvelse før udskrivning. ${ }^{12}$

\section{Psykiatri og retspsykiatri}

En væsentlig kilde til forskelle de tre lande imellem er den måde psykiatrien er opbygget på, og de regler den er underlagt, både i forhold til patienter der udgør en risiko for lovovertrædelser, og patienter som er dømt for en lovovertrædelse. Der er særlig grund til at se nærmere på hvordan psykiatrien indgår i straffesagen, hvilke institutioner der indgår i gennemførelsen af en dom til behandling, og hvilke tvangsmuligheder psykiatrien har over for (potentielt) farlige patienter.

I den norske psykiatri er der ikke etableret særlige retspsykiatriske afdelinger, hverken med henblik på bistand under straffesager eller med henblik på behandling. Den sagkyndige bistand opnås ved at retten til brug for sagen indhenter en udtalelse fra to retspsykiatrisk sagkyndige, hvoraf den ene skal være psykiater. ${ }^{13}$ Efter psykisk helsevernslovens § 5-3 er der krav om at en person der har fået dom på overføring til tvungent psykisk helsevern de første tre uger skal indlægges på en psykiatrisk institution, men derudover styres forløbet af den behandlingsansvarlige på hvilkår der minder om dem patienter indlagt uden dom er underlagt.

I Danmark er der inden for psykiatrien etableret retspsykiatriske behandlingsafdelinger. Disse afdelinger indgår som en del af den regionale psykiatri, og det er således op til den enkelte region hvordan patienterne fordeles mellem retspsykiatriske og almen-psykiatriske afdelinger. I forbindelse med straffeprocessen udarbejdes mentalerklæringer på bestilling af politiet. ${ }^{14}$ Langt de fleste erklæringer udarbejdes ved ambulante undersøgelser ved retspsykiatriske afdelinger i de enkelte regioner, eller ved Justitsministeriets Retspsykiatriske Klinik i København.

Svensk retspsykiatri er opdelt i to separate spor. I forbindelse med straffesager ydes den retspsykiatriske bistand fra det statslige Rättsmedicinalverket. I tilfælde hvor en tiltalt er varetægtsfængslet udarbejdes undersøgelsen ved indlæggelse på en af Rättsmedicinalverkets institutioner. ${ }^{15}$ På regionalt niveau er der oprettet retspsykiatriske behandlingsinstitutioner under den regionale psykiatri.

Et interessant sammenligningspunkt er spørgsmålet om hvilke muligheder psykiatrien har for at tvangsbehandle en patient som ikke er underlagt en strafferetlig reaktion. Efter psykisk helsevernsloven § 3-3 kan der i norsk psykiatri træffes afgørelse om tvungen behandling såfremt dette er nødvendigt af behandlingseller beskyttelseshensyn. Behandlingen skal tage den form der er mest hensigtsmæssig, og ambulant behandling skal anvendes såfremt dette er et bedre alterna- 
tiv end tvangsindlæggelse, jf. $\S 3-5$. I den modsatte ende af skalaen ligger dansk psykiatri, hvor kriterierne for tvungen behandling i store træk ligner de norske, men hvor tvungen behandling som altovervejende udgangspunkt kun kan ske ved døgnophold på institution. I Sverige blev muligheden for ambulant tvangsbehandling indført i 2008.

\section{Komparative bemærkninger}

De præsenterede forskelle på retssystemerne, og mit arbejde med projektet indtil videre, har givet anledning til en række komparative overvejelser. I det følgende vil jeg fokusere på tre endnu åbne spørgsmål som den komparative undersøgelse har givet anledning til:

For det første er der meget der tyder på at der fra et funktionelt perspektiv er grund til at se anderledes på særligt det danske og det svenske system end det har været gjort hidtil. Traditionelt betragtes det svenske regelsæt, hvor der ikke arbejdes med et utilregnelighedskriterium, som noget unikt, hvorimod det danske og det norske opfattes som to systemer der blot adskilles af en mindre afvigelse $i$ valget af utilregnelighedskriterium. Funktionelt er der imidlertid meget der taler for at betragte Sverige og Danmark som de mest sammenlignelige systemer i dette tilfælde.

Selv om bestemmelserne i den danske straffelovs $\S 16$ og $\S 68$ i princippet er uafhængige, og således lægger op til at spørgsmålet om utilregnelighed bør vurderes adskilt fra spørgsmålet om reaktion, ligger kriterierne så tæt op af hinanden at overvejelserne ved straffesagen ofte reelt bliver et spørgsmål om valg mellem fængsel eller foranstaltning. ${ }^{16}$ Det meget åbne utilregnelighedskriterium i $\S 16$ efterlader vid mulighed for at tage hensyn til hvilken foranstaltning der er grundlag for, når der tages stilling til spørgsmålet om straffrihed.

Omvendt indgår der i de svenske regler nogle momenter som er hentet fra traditionelle overvejelser om manglende tilregnelighed. Det afgørende moment i den negative afgrænsning af muligheden for at idømme fængsel efter brottsbalkens $\S 30: 6$ er således ikke om der foreligger en allvarlig psykisk störning på domstidspunktet, men om lovovertrædelsen er begået under påvirkning af en sådan. Dette princip er særligt tydeligt efter lovændringen i 2008, hvor det absolutte fængselsforbud direkte betinges af at gerningsmanden »saknat förmåga att inse gärningens innebörd eller att anpassa sitt handlande efter en sådan insikt «. Uanset at utilregnelighed på grund af psykisk sygdom formelt ikke indgår i det svenske straffesystem, genfindes tankegangen således i høj grad i sanktionsvalgsreglerne.

En tilsvarende sammensmeltning af de negative og de positive kriterier synes ikke i samme grad at finde sted i Norge. Det rent retspsykiatriske kriterium i den 
norske straffelovs $\S 44$ afskærer i et vist omfang domstolene fra at inddrage alternative reaktionsmuligheder i overvejelsen om om kriteriet for straffrihed er opfyldt. Samtidigt modvirker både nødvendigheds- og kriminalitetskravet i straffelovens $\S 39$ en tilnærmelse af det negative og det positive kriterium.

Hvor stor den praktiske indflydelse af denne forskel er, er endnu et åbent spørgsmål. Mere konkret er forskellen på det andet punkt: Det meget markante spring $\mathrm{i}$ antallet af domme til psykiatrisk behandling mellem på den ene side Danmark og Sverige, og på den anden side Norge. Hvor antallet af årlige domme til psykiatrisk behandling i både Danmark og Sverige måles i hundreder, er der meget langt mellem norske domme på overføring til tvungent psykisk helsevern. Hvad er årsagen til denne betydelige forskel?

Afgrænsningen af de tilstande som omfattes er gjort forskelligt i de tre lande. En del af forskellen i antal kunne således forklares med at kriterierne "psykotisk eller bevisstløs«, »sindssygdom eller tilstande der må ligestilles hermed « og »allvarlig psykisk störning « rammer forskellige persongrupper. En sådan forskel vil dog kun kunne forklare en begrænset del af afvigelserne.

Forskellen i psykiatriens muligheder for tvangsbehandling uden strafferetlig dom kan også være en mulig forklaring på i hvert fald en del af forskellen. Det norske psykiatriske system har tilsyneladende langt bedre værktøjer til at gribe ind og sikre behandling af farlige patienter uden nødvendigvis at være nødt til at gribe til døgnindlæggelse. Dette kan betyde at en række af de tilfælde som i Danmark og Sverige ender i det strafferetlige system, bliver løst ved behandling uden dom i Norge.

En stor del af forskellen kan forklares ved det norske kriminalitetskrav i § 44 . Ser man på den kriminalitet der ligger bag danske foranstaltningsdomme, er det for eksempel kun omkring $40 \%$ der har en karakter som er omfattet af ordlyden i den norske straffelovs $\S 44$, og hvis kriminalitetskravet følges stramt i Norge vil det kunne forklare en endnu større del af forskellen. ${ }^{17}$

Endelig kan forskelle i reaktionsmulighederne have en betydning. En norsk dom på overføring til tvungent psykisk helsevern medfører minimum tre ugers indlæggelse, hvor både de svenske og særligt de danske regler giver mulighed for mildere reaktioner. Dette kan have indflydelse på viljen til at bruge dom til psykiatrisk behandling som værktøj i sager der ikke lægger op til så omfattende reaktioner.

En afsluttende pointe som er værd at nævne er at der synes at være forskel på hvordan de pågældende personer opfattes både i psykiatrien og i retssystemet. Det er mit indtryk at psykisk syge lovovertrædere i den norske debat i højere grad opfattes som patienter, og at en dom på overføring til tvungent psykisk helsevern kun i mindre grad opfattes som en strafferetlig dom, end det tilsvarende er tilfæl- 
det i Danmark og Sverige. Man kan få det indtryk at en dom på overføring til tvungent psykisk helsevern i højere grad opfattes som en dom der pålægger psykiatrien at sikre den nødvendige behandling og samfundsbeskyttelse, end en dom over den enkelte lovovertræder.

Alle tre problemstillinger er som sagt endnu åbne på nuværende tidspunkt $\mathrm{i}$ projektet, men de tjener allerede nu til at illustrere hvordan en komparativ tilgang til spørgsmålet om psykisk syge lovovertrædere kan give et andet perspektiv på reglerne om psykisk syge lovovertrædere end hvad der måtte fremkomme ved en rent dogmatisk analyse af reglerne.

\section{Noter}

1. Simon Engell Kamber er ph.d.-stipendiat ved Juridisk Institut, Aarhus Universitet

2. World Health Organization: The ICD-10 Classification of Mental and Behavioural Disorders - Clinical descriptions and diagnostic guidelines, WHO 1992 (Blue Book), s. 10

3. Jacobsen, Jørn RT: Dom på overføring til tvungent psykisk helsevern, Fagbokforlaget 2004, s. 40

4. Jacobsen: Op. cit., s. 57ff

5. Utredningsgruppe oppnevnt av Justis- og politidepartementet 18. maj 2006: Etterkontroll av reglene om strafferettslig utilregnelighet, strafferettslige særreaksjoner og forvaring, Justisog politidepartementet 2008 (Mæland-utvalget), side 132

6. Greve, Vagn; Nielsen, Asbjørn; Jensen, Poul Dahl og Nielsen, Gorm Toftegaard: Kommenteret Straffelov - Almindelig Del, 9. udgave, Jurist- og Økonomforbundets Forlag 2009 s. 208ff og 374f.

7. Kramp, Peter; Lunn, Villars og Waaben, Knud: Retspsykiatri, GadJura 1996, s. 69

8. Brandt-Christensen, Mette og Bertelsen, Aksel: Sindssygdomsbegrebet i straffelov og psykiatrilov, Ugeskrift for loeger 2010, 1274-1276

9. Denne åbenhed i begrebet var netop intentionen bag bestemmelsen. Et mere velafgrænset kriterium blev af mindretallet bag den foreslåede formulering afvist med den begrundelse at begrebet utilregnelighed måtte tages $\mathrm{i}$ »sin naturlige Betydning« (Bet. 1923, s. 63)

10. Justitsministeriets Forskningskontor: Nye Foranstaltningsdomme i 2011 samt forløbet af domme afsagt i 2006, Justitsministeriet 2012, s. 4

11. Lidberg, Lars og Wiklund, Nils: Svensk rättspsykiatri - Psykisk störning, brott och påföljd, andra upplagan, Studentlitteratur 2004, s. $120 \mathrm{ff}$

12. Jareborg, Nils og Zila, Josef: Straffrättens påföljdslära, tredje upplagan, Norstedts Juridik 2010 , s. $166 \mathrm{ff}$

13. Jacobsen: Op. cit., s. 168

14. Kramp, Lunn og Waaben: Op. cit., s. 168

15. Lidberg og Wiklund: Op. cit., s. 149ff 
16. Denne sammensmeltning ses direkte i retsplejelovens $\S \S 891$ og 894 , hvoraf det fremgår at spørgsmålet om straffrihed på grund af psykisk sygdom i nævningesager behandles sammen med sanktionsspørgsmålet, efter at der er afsagt kendelse om skyld.

17. Justitsministeriets Forskningskontor: Op. cit., s. 2 